\title{
The Carboxypeptidase Activity of Cathepsin X is not Controlled by Endogenous Inhibitors
}

\author{
Urša Pečar Fonović, ${ }^{1, \star}$ Milica Perišić Nanut, ${ }^{2}$ Nace Zidar, ${ }^{1}$ Brigita Lenarčič ${ }^{3}$ \\ and Janko Kos ${ }^{1,2}$ \\ ${ }^{1}$ Faculty of Pharmacy, University of Ljubljana, Aškerčeva 7, 1000 Ljubljana, Slovenia \\ ${ }^{2}$ Department of Biotechnology, Jožef Stefan Institute, Jamova 39, 1000 Ljubljana, Slovenia \\ ${ }^{3}$ Faculty of Chemistry and Chemical Technology, University of Ljubljana, Večna pot 113, 1000 Ljubljana, Slovenia \\ *Corresponding author: E-mail: ursa.pecarfonovic@ffa.uni-lj.si \\ Tel.: +38614769 500; Fax: +38614258 031
}

Received: 04-26-2018

Dedicated to the memory of Prof. Dr. Igor Kregar

\begin{abstract}
Cysteine cathepsins are peptidases with housekeeping functions that play different specific roles in different tissues. Endogenous peptidase inhibitors, such as cystatins and thyropins are the ultimate way of controlling their activity. It appears, however, that cathepsin $\mathrm{X}$, a monocarboxypeptidase, whose overexpression is associated with several pathological processes, is not under the control of endogenous inhibitors. Inhibitors belonging to various groups inhibit other cathepsins tested, but none decrease the carboxypeptidase activity of cathepsin X. This absence of inhibitor control is another feature that distinguishes cathepsin X from other members of the cysteine peptidases.
\end{abstract}

Keywords: Cathepsin X; inhibitor; cystatin; stefin; thyropin

\section{Introduction}

Lysosomal cysteine cathepsins are expressed in the form of inactive precursors. When activated, their activity is controlled by endogenous inhibitors. ${ }^{1}$ These inhibitors are divided into superfamilies of cystatins (which includes stefins, cystatins, kininogens and non-inhibitory fetuins) and thyropins. ${ }^{2}$ Physiologically, endogenous inhibitors can act as emergency inhibitors that usually act on peptidases released from cells or lysosomes, from infecting microorganisms, or as regulatory inhibitors modulating peptidase activity. Regulatory inhibitors are further divided into 1) the threshold inhibitors that act when there is accidental activation of peptidases, 2) buffer type inhibitors that keep peptidases inactive in the absence of substrate or 3) delay type inhibitors that bind slowly to the active enzyme, allowing its action for a certain period of time. ${ }^{2}$

Cathepsin $\mathrm{X}$ is a carboxypeptidase expressed predominantly in immune and neuronal cells. ${ }^{3}$ It regulates the migration, adhesion, proliferation, and maturation of cells, together with phagocytosis and signal transduction. ${ }^{4}$ Its overexpression, increased activation or mislocalization may trigger pathological processes such as cancer, ${ }^{5-9}$ neurodegenerative disorders ${ }^{10}$ or inflammatory diseases. ${ }^{11}$

Studies describing the inhibitory action of endogenous peptidase inhibitors towards cathepsin $\mathrm{X}$ are rare and contradictory. While some did not report inhibition of cathepsin $\mathrm{X}$ by cystatins $\mathrm{C}$ and $\mathrm{F}^{12-15}$, others reported its potent inhibition by cystatin $\mathrm{C}^{16}$ as well as by stefins $\mathrm{A}$ and $\mathrm{B}$ and chicken cystatin, but not by L-kininogen.

The aim of this study was to evaluate the inhibitory effect of a broader range of endogenous protease inhibitors from the cystatin and thyropin families on cathepsin $\mathrm{X}$ in comparison to the related cathepsins B and L. In the assay a recombinant cathepsin $\mathrm{X}$, void of contamination with other cathepsins, and its specific substrate Abz-FEK(Dnp) $\mathrm{OH}$ were used.

\section{Experimental}

Activity assays were performed with recombinant cathepsins X (prepared in P.pastoris),${ }^{17} \mathrm{~B}$ and $\mathrm{L}$ ( both prepared in E.coli). ${ }^{18,19}$ Assay buffers were $100 \mathrm{mM}$ sodium acetate buffer, pH 5.5 (for cathepsins $\mathrm{X}$ and $\mathrm{L}$ ), $60 \mathrm{mM}$ 
acetate buffer pH 5.0 (for cathepsin B exopeptidase activity) and $100 \mathrm{mM}$ phosphate buffer $\mathrm{pH} 6.0$ (for cathepsin $\mathrm{B}$ endopeptidase activity). All assay buffers contained $5 \mathrm{mM}$ cysteine, $1.5 \mathrm{mM}$ EDTA and 0.1\% PEG 8000. Enzymes were activated in the assay buffer at $37^{\circ} \mathrm{C}$ for $5 \mathrm{~min}$ before assay. ${ }^{16}$ Cystatin $\mathrm{F}$ was activated for $15 \mathrm{~min}$ at $37^{\circ} \mathrm{C}$ in the appropriate assay buffer containing $100 \mathrm{mM}$ cysteine. ${ }^{15}$ The fluorogenic substrates Abz-FEK(Dnp)-OH, ${ }^{20} \mathrm{Z}$-FRAMC, Abz-GIVRAK(Dnp)-OH ${ }^{21}$ and Z-RR-AMC were used for determining cathepsins $\mathrm{X}, \mathrm{L}$ and $\mathrm{B}$ exo- and endopeptidase activities, respectively. Cystatin $\mathrm{F}$ (wild type and truncated form $\Delta 15 \mathrm{~N}$ ) was expressed in FreeStyle 293F cells, ${ }^{22}$ chicken cystatin was isolated from chicken egg white, ${ }^{23}$ recombinant cystatin $\mathrm{C}$ and stefins $\mathrm{A}$ and $\mathrm{B}$ were expressed in $E$. coli, ${ }^{24,25}$ thyropins were from the laboratory of B. Lenarčič. Enzymes, substrates and inhibitor concentrations are summarized in Supplementary Table S1.

$90 \mu \mathrm{L}$ of activated enzyme ( $20 \mathrm{nM}$ cathepsin X or 0.5 $\mathrm{nM}$ cathepsin $\mathrm{L}$ or $0.6 \mathrm{nM} / 5.5 \mathrm{nM}$ cathepsin $\mathrm{B}$ for its exo/ endopeptidase activity) was incubated for 30 min with $5 \mu \mathrm{L}$ of the inhibitor (100-fold molar excess over the enzyme) at $37^{\circ} \mathrm{C}$, then added to a black 96-well plate together with 5 $\mu \mathrm{L}$ of substrate. The reaction was monitored continuously, at $37^{\circ}$, at $420 \times 10 \mathrm{~nm}$ with excitation at $320 \times 20 \mathrm{~nm}$ for Abz substrates and at $460 \mathrm{~nm} \times 10 \mathrm{~nm}$ with excitation at $380 \mathrm{~nm} \times 20 \mathrm{~nm}$ for AMC substrates.

\section{Results and Discussion}

Various peptidase inhibitors were tested in a standard kinetic assay to determine inhibition of cathepsin X.
Previous reports of their inhibitory activities towards cathepsin $\mathrm{X}$ are ambiguous, probably due to the use of native cathepsin $\mathrm{X}$, isolated from human liver, later shown to be contaminated with cathepsin $\mathrm{B}^{12}$ or of recombinant cathepsin $\mathrm{X}$ contaminated with cathepsin $\mathrm{L}$ which is needed for the activation of procathepsin $\mathrm{X} .{ }^{26}$ The substrates used, such as FR-AMC, were not specific, being also degraded by other cathepsins. Since most of the cystatins used in these studies (cystatin C, chicken cystatin, stefins $A$ and $B)^{16}$ potently inhibit cathepsins $\mathrm{L}$ and $B$, it is very likely that the measured inhibition was in fact that of contaminating cathepsin B or L. In our study we used recombinant cathepsin X, containing cathepsin $\mathrm{L}$ below the detection limit of western blot and ELISA assays, ${ }^{17}$ and cathepsin X specific substrate Abz-FEK(Dnp)-OH. ${ }^{26}$ The tested inhibitors (in 100-fold molar excess) did not significantly inhibit cathepsin X (Figure 1). The irreversible inhibitor of cysteine peptidases, E-64, was used as a control.

Inhibitors from the cystatin and thyropin families were included in the study, namely cystatins C, F (wild type and $\mathrm{N}$-terminally truncated form ${ }^{15}$ ), chicken cystatin, stefins $A$ and B, p41, equistatin, testicans 1 and 2 and thyroglobulin domains of nidogens 1 and 2 (domain 1 from nidogen 1 and domains 1 and 2 from nidogen 2). The results demonstrate the absence of inhibition, even at high inhibitor to enzyme ratios and are in line with studies on cystatins $\mathrm{C}$ and $\mathrm{F}^{12-15}$ Inhibitory activity of thyropins has not yet been probed for cathepsin X. Like cystatins, they did not inhibit cathepsin X.

The same set of inhibitors was tested on endo- and exopeptidase (carboxypeptidase) activities of cathepsin B

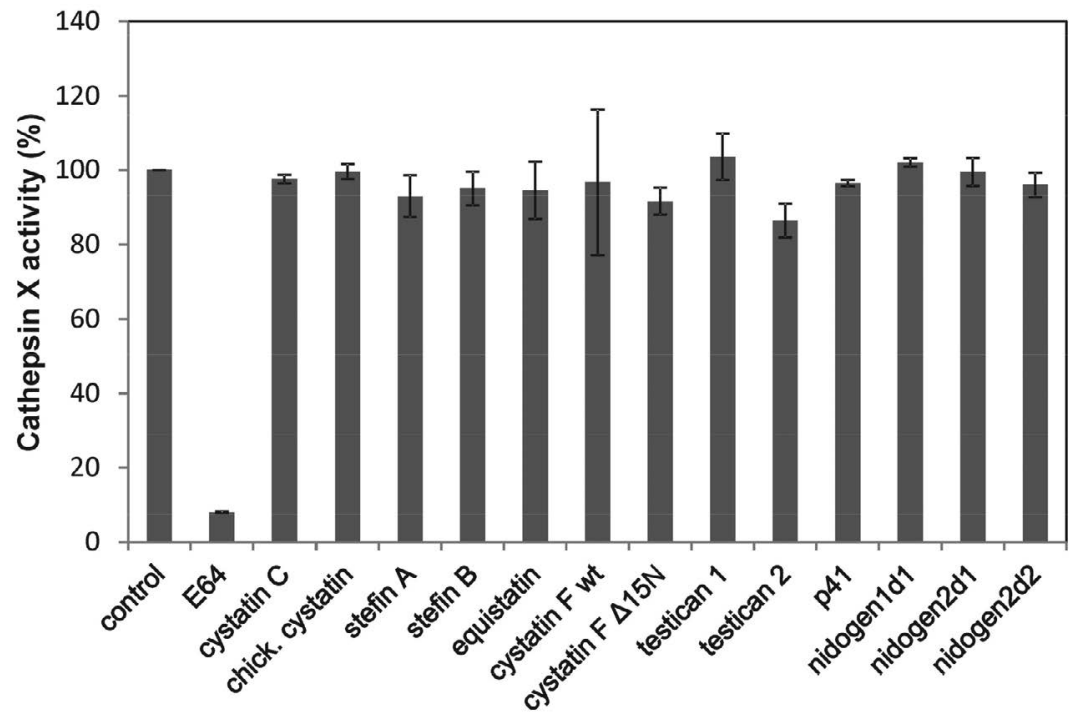

Figure 1: Cathepsin $\mathrm{X}$ is not inhibited by endogenous peptidase inhibitors.

Relative inhibition of cathepsin X by various inhibitors was tested in a kinetic assay. Concentrations of endogenous inhibitors were $2 \mu \mathrm{M}$ (100-fold higher than that of the enzyme), while E-64 was tested at $10 \mu \mathrm{M}$ concentration. Assay buffer was used in a control experiment. Values are the means of two or three independent experiments, each performed in duplicate \pm SEM. 


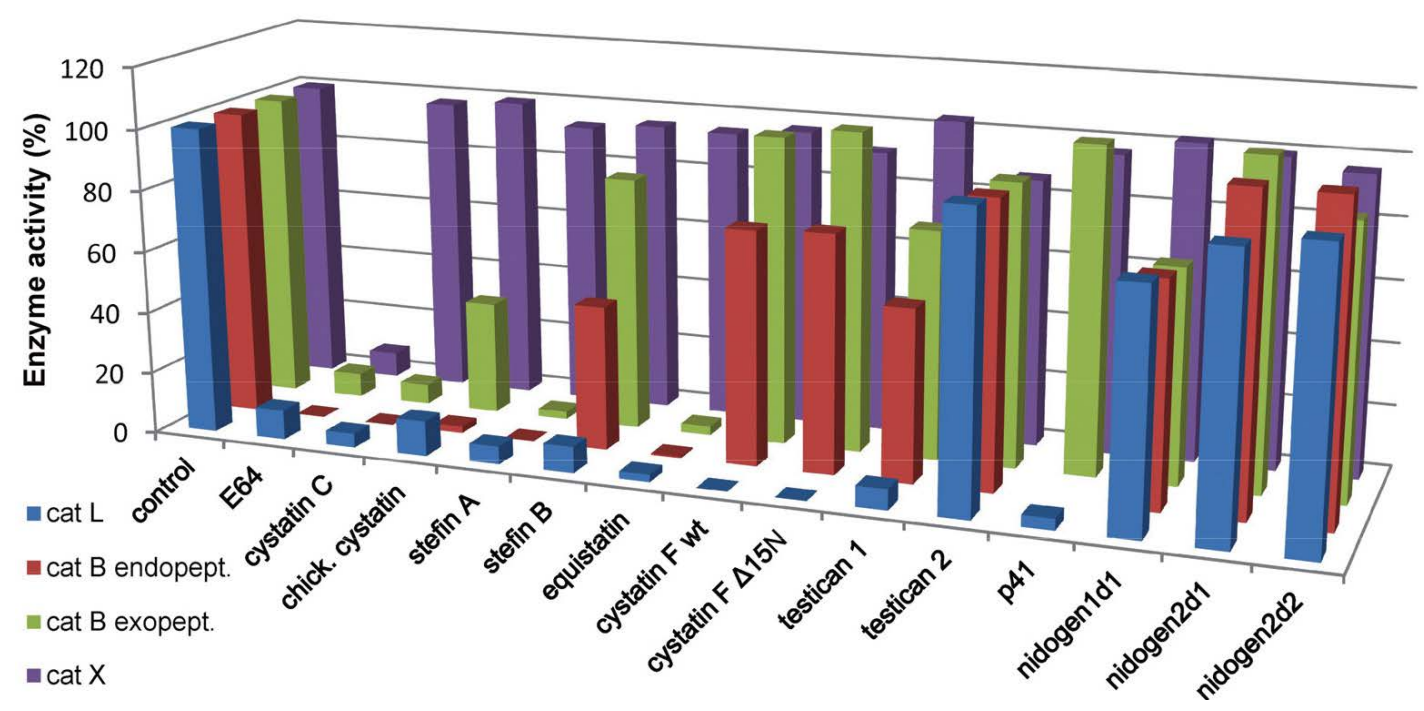

Figure 2: Comparison of the activities of endogenous inhibitors towards cathepsins X, B (exo- and endopeptidase activity) and L.

The relative inhibitiory activities of cysteine cathepsins with various inhibitors was tested in a kinetic assay (p41 was not tested on cathepsin B endopeptidase activity). Concentrations of inhibitors were 100-fold higher than those of the enzymes, E-64, used as a positive control, was tested at 10 $\mu \mathrm{M}$ concentration. Assay buffers were used in control experiments. Values are the means of two or three independent experiments, each performed in duplicate.

(Figure 2). Cystatin C, stefin A and equistatin potently inhibit both, endopeptidase and exopeptidase activities of cathepsin B, whereas stefin B, cystatin F and testican 1 are better inhibitors of endopeptidase activity. We also determined their inhibitory activities towards cathepsin $\mathrm{L}$ (Figure 2). As reported, cathepsin L was inhibited by the majority of inhibitors except testican 2 and nidogen $2{ }^{27,28}$ Nidogen 1 was not very effective in inhibiting cathepsin L.

\section{Conclusions}

Our results show that endogenous inhibitors of cysteine peptidases do not inhibit cathepsin X. Thus cathepsin X carboxypeptidase activity escapes this ultimate control. The possible physiological and pathological consequences of this observation have, however, not yet been addressed. The inhibition of other cathepsins, tested in parallel to cathepsin $\mathrm{X}$ with the same set of inhibitors, demonstrates a great difference in their potency, contrary to the general opinion that cystatins and thyropins act in a broad, nonspecific fashion.

\section{Acknowledgement}

The authors thank prof. Roger Pain for a critical review of the manuscript. This work was supported by the Slovenian Research Agency grant P4-0127 (JK).

\section{References}

1 B. Turk, D. Turk, V. Turk. EMBO J 2012, 31, 1630-1643. https://doi.org/10.1038/emboj.2012.42

2 B. Turk, D. Turk, G. S. Salvesen, Curr Pharm Des 2002, 8, 16231637. DOI:https://doi.org/10.2174/1381612023394124

3 J. Kos, A. Sekirnik, A. Premzl, V. Zavašnik Bergant, T. Langerholc, B. Turk, B. Werle, R. Golouh, U. Repnik, M. Jeras, V. Turk, Exp Cell Res 2005, 306, 103-113.

DOI:https://doi.org/10.1016/j.yexcr.2004.12.006

4 J. Kos, Z. Jevnikar, N. Obermajer, Cell Adh Migr 2009, 3, 164 166. DOI:https://doi.org/10.4161/cam.3.2.7403

5 G. Rumpler, B. Becker, C. Hafner, M. McClelland, W. Stolz, M. Landthaler, R. Schmitt, A. Bosserhoff, T. Vogt, Exp Dermatol 2003, 12, 761-771.

DOI:https://doi.org/10.1111/j.0906-6705.2003.00082.x

6 D. K. Nägler, S Kruger, A. Kellner, E. Ziomek, R. Menard, P. Buhtz, M. Krams, A. Roessner, U. Kellner, Prostate 2004, 60, 109-119. DOI:https://doi.org/10.1002/pros.20046

7 S. Krueger, T. Kalinski, T. Hundertmark, T. Wex, D. Kuster, U. Peitz, M. Ebert, D.K. Nagler, U. Kellner, P. Melfertheiner, M. Naumann, C. Rocken, A. Roesnner, J Pathol 2005, 207, 32-42. DOI:https://doi.org/10.1002/path.1820

8 J. Wang, L. Chen, Y. Li, X. Y. Guan, PLoS One 2011, 6, e24967. DOI:https://doi.org/10.1371/journal.pone.0024967

9 T. Vižin, I. J. Christensen, M. Wilhelmsen, H. J. Nielsen, J. Kos, BMC Cancer 2014, 14, 259.

DOI:https://doi.org/10.1186/1471-2407-14-259

10 A. Pišlar, J. Kos, Mol Neurobiol 2014, 49, 1017-1030.

DOI:https://doi.org/10.1007/s12035-013-8576-6

11 D. K. Nägler, A. M. Lechner, A. Oettl, K. Kozaczynska, H. P. 
Scheuber, C. Gippner-Steppert, V. Bogner, P. Biberthaler, M. Jochum, J Immunol Methods 2006, 308, 241-250.

DOI:https://doi.org/10.1016/j.jim.2005.11.002

12 C. Therrien, P. Lachance, T. Sulea, E. O. Purisima, H. Qi, E.Ziomek, A. Alvarez-Hernandez, W. R: Roush, R. Menard, Biochemistry, 2001, 40, 2702-2711.

DOI:https://doi.org/10.1021/bi002460a

13 D. K. Nägler, R. Zhang, W. Tam, T. Sulea, E. O. Purisima, R. Ménard, Biochemistry 1999, 38, 12648-12654 (1999).

DOI:https://doi.org/10.1021/bi991371z

14 T. Langerholc, V. Zavasnik-Bergant, B. Turk, V. Turk, M. Abrahamson, J. Kos, FEBS J 2005, 272, 1535-1545.

DOI:https://doi.org/10.1111/j.1742-4658.2005.04594.x

15 S. Magister, N. Obermajer, B. Mirković, U. Svajger, M. Renko, A. Softić, R. Romih, J. D. Colbert, C. Watts, J. Kos, Eur J Cell Biol 2012, 91, 391-401.

DOI:https://doi.org/10.1016/j.ejcb.2012.01.001

16 I. Klemencic, A. K. Carmona, M. H. Cezari, M. A. Juliano, L. Juliano, G. Guncar, D. Turk, I. Krizaj, V. Turk, B. Turk, Eur J Biochem 2000, 267, 5404-5412.

DOI:https://doi.org/10.1046/j.1432-1327.2000.01592.x

17 U. Pečar Fonović, J. Kos, Acta Chim. Slov. 2009, 56, 985-988.

18 R. Kuhelj, M. Dolinar, J. Pungercar, V. Turk, Eur J Biochem $1995,229,533-539$.

DOI:https://doi.org/10.1111/j.1432-1033.1995.0533k.x
19 M. Dolinar, D. B. Maganja, V. Turk, Biol Chem Hoppe Seyler 1995, 376, 385-388.

DOI:https://doi.org/10.1515/bchm3.1995.376.6.385

20 A. M. Sadaghiani, S. H. Verhelst, V. Gocheva, K. Hill, E. Majerova, S. Stinson, J. A. Joyce, M. Bogyo, Chem Biol 2007, 14, 499-511.

DOI:https://doi.org/10.1016/j.chembiol.2007.03.010

21 S. S. Cotrin, L. Puzer, W. A. de Souza Judice, L. Juliano, A.K. Carmona, M. A. Juliano. Anal Biochem 2004, 335, 244-252. DOI:https://doi.org/10.1016/j.ab.2004.09.012

22 M. Perišić Nanut, J. Sabotič, U. Švajger, A. Jewett, J. Kos, Front Immunol 2017, 8, 1459.

DOI:https://doi.org/10.3389/fimmu.2017.01459

23 W. Bode, R. Engh, D. Musil, U. Thiele, R. Huber, A. Karshikov, J. Brzin, J. Kos, V. Turk, EMBO J 1988, 7, 2593-2599.

24 N. Cimerman, Preparation of some recombinant human cystatin C mutants and their characterisation, Ph.D. thesis, University of Ljubljana, Slovenia, 1993.

25 R. Jerala, E. Zerovnik, K. Lohner, V. Turk, Protein Eng 1988, 7, 977-984. DOI:https://doi.org/10.1093/protein/7.8.977

26 L. Puzer, S. S. Cotrin, M. H. Cezari, I. Y. Hirata, M. A. Juliano, I. Stefe, D. Turk, B. Turk, L. Juliano, A. K. Carmona, Biol Chem 2005, 386, 1191-1195.

27 A. Leonardi, B. Turk, V. Turk, Biol Chem Hoppe Seyler. 1996, 377, 319-21.

28 P. Meh, M. Pavsic, V. Turk, A. Baici, B. Lenarcic, Biol Chem 2005 386, 75-83. DOI:https://doi.org/10.1515/BC.2005.010

\section{Povzetek}

Cisteinski katepsini so peptidaze z vzdrževalno vlogo in z različnimi specifičnimi vlogami v različnih tkivih. Endogeni inhibitorji peptidaz, kot so cistatini in tiropini, so bistveni za nadzor njihove aktivnosti, vendar pa rezultati kažejo, da katepsin X, monokarboksipeptidaza, katere prekomerno izražanje je povezano $\mathrm{z}$ več patološkimi procesi, ni pod nadzorom endogenih inhibitorjev. Inhibitorji, ki pripadajo različnim skupinam, so zavirali druge preizkušene katepsine, nobeden pa ni zmanjšal karboksipeptidazne aktivnosti katepsina X. Odsotnost takega nadzora $\mathrm{z}$ inhibitorji, je še ena značilnost, ki razlikuje katepsin X od drugih članov cisteinskih peptidaz. 